\title{
Ha ELVÉSZ A BIZALOM
}

\author{
PUSZTAI GABRIELLA
}

Debreceni Egyetem

A hallgatói bizalom nemcsak az individuumszintű hallgatói jóllét egyik erős tartópillére, hanem - mivel a bizalom és a megbízható magatartás szoros összefüggésben áll egymással - jelentős társadalmi tény, s egyben előrejelzés a következő felnőtt állampolgári generáció társadalmi magatartására vonatkozólag. Tanulmányunkban egyrészt azt vizsgáljuk, hogy milyen törésvonalak mentén rendeződik el a bizalom napjaink hallgatótársadalmában, milyen hatással van a felsőoktatási hallgatók teljesítményére, milyen forrásból ered, valamint arra keressük a választ, hogy a lemorzsolódásban milyen szerepe lehet a bizalomvesztésnek. Három adatbázis adatait elemeztük Magyar Ifjúság 2016, A hallgatói eredményességre gyakorolt intézményi hatás (IESA 2015) és a Lemorzsolódottak (Depart 2018 ${ }^{1}$ ). Az elemzés során azt tapasztaltuk, hogy az országos hallgatói adatok szerint a közintézményekbe vetett bizalom szintje a szülői iskolázottsággal meghatározott státus mentén jelentős eltéréseket mutat, az egyenlőtlenségeket tovább színezik a vallásosság szerinti különbségek. A kelet-magyarországi intézmények hallgatói között azonban egyenletesen magas a bizalmatlanok aránya. A felsőoktatási tanulmányi kudarcot szenvedők bizalomszintje alacsony, a lemorzsolódottak a bizalom megroppanásával magyarázzák tanulmányaik félbehagyását. Noha a nevelési-oktatási hatékonyság alapfeltétele lenne a szereppartnerek közötti bizalomteljes kapcsolat, a tömegessé, majd üzletiessé vált felsőoktatásban a hallgatók domináns élménye az oktatói odafigyelés nélkülözése és a személytelenség.

Kulcsszavak: felsőoktatás, bizalom, eredményesség, lemorzsolódás

Students' trust is not only one of the strong pillars of student well-being, but - as trust and trustworthiness are closely related - it predicts many dimensions of the social behavior of the future generation. In our study we research, 1) on the one hand, which are the lines along which the trust in today's student society is settled (social status, cultural affiliations, regional situation), 2) on the second hand we investigate the impact of trust and its effect on the performance of higher education students, and 3) thirdly we try to find out what role distrust plays in students dropouts. We use data from three databases were analyzed by Hungarian Youth 2016, Institutional Effect on Student Achievement (IESA 2015) and Depart 2018). During the analysis we found that

Levelező szerző: Pusztai Gabriella, Debreceni Egyetem, 4032 Debrecen, Egyetem tér 1.

E-mail: gabriela.pusztai@gmail.com

1 A 123847 számú projekt a Nemzeti Kutatási Fejlesztési és Innovációs Alapból biztosított támogatással, a K_17 pályázati program finanszírozásában valósult meg. 
according to the national student data, the level of trust in public institutions shows significant differences along the status determined by parental education. However, among the students of the institutions of Eastern Hungary there were no significant differences between the two inequality dimensions observed, as the proportion of the distrusts was very high in all groups. The low level of trust has a significant correlation with the abandonment of studies, the reluctance to reenter the institution, and with the uncertainty that predicts dropping out. The overwhelming majority of the dropouts explain the failure of their studies with the collapse of confidence.

Keywords $¥$ higher education, trust, student performance, dropout

\section{A hallgatói bizalom jelentősége}

$\mathrm{N}$ emzetközi összehasonlításban a közép-európai posztkommunista országok, s különösen Magyarország lakói az erősen bizalmatlanok táborába tartoznak. Mindez nem magyarázható egyszerűen a régióban élők kedvezőtlenebb gazdasági státusával (Tóth 2010). A bizalmatlanság intergenerációs és társadalmi méretű átörökítése, a bizalom és a megbízható magatartás szoros összefüggései arra figyelmeztetnek, hogy lényeges kutatási feladat nyomon követni a leendő diplomások ezzel kapcsolatos magatartását.

Az egy évtizeddel ezelőtt végzett hallgatói kutatásunk során, mely a felsőoktatási intézményi kapcsolathálózati beágyazottság hallgatói eredményességre gyakorolt hatását vizsgálta, a hallgatói bizalmat a hallgatói kultúra egyik pilléreként interpretáltuk, amely az arra vonatkozó vélekedést foglalja magába, hogy a hallgatói célelérést az intézményi és interperszonális kapcsolathálóban várhatóan ki támogatja (Pusztai 2011). Az erre vonatkozó egyéni vagy közösségi meggyőződés összegződik a hallgatói bizalommintázatokban. Azt tapasztaltuk, hogy alig minden második hallgató tekint bizalommal a környezetére. Azt is megfigyeltük, hogy a kapcsolathálók, a kampusz társas kontextusa jobban befolyásolja a legtöbb hallgató bizalomszintjét, mint saját családjuk társadalmi státusa (Pusztai 2011). Lényeges eredmény volt, hogy a felsőoktatási intézmény tanulmányi és társas közegébe való intergenerációs beágyazottsággal, a produktív oktató-hallgató kapcsolatokkal rendelkező kisebbség még abban az esetben is megbízott a rektorban, a dékánban és az oktatókban, ha a hallgatótársaik többsége épp ellentétes véleményen volt. Az intergenerációs beágyazottságú hallgatók jobban bíztak a közintézményekben is. Ezzel szemben az izolált hallgatók mindenkivel szemben nagyon bizalmatlanok voltak (Pusztai 2011). Az alacsony bizalomszint az egyetem tudományos és tanulmányi normáinak kétségbevonásával, sőt kijátszásával, normaszegéssel járt együtt (Pusztai 2011).

Jelen tanulmány első részében azt gondoljuk végig, hogy milyen speciális értelmezése van a bizalomnak az oktatás világában, majd empirikus adatokat elemezve arra keressük a választ, hogy milyen társadalmi különbségek mentén rendeződik el a bizalom a hallgatótársadalomban, milyen hatással van a felsőoktatási hallgatók teljesítményére, s milyen következménye van annak, ha megrendül a bizalom. 


\section{A bizalom és az oktatás világa}

A fent hivatkozott kutatásunk során alkalmazott definícióra építve, értelmezésünk szerint az oktatás világában a bizalom az a meggyőződés, hogy az oktatási rendszer, az oktatási intézmények és szakemberek a hallgató által ismert jogi, etikai szabályoknak és működési rendnek megfelelően funkcionálnak, s támogatják az egyént a belépéskor közösen meghatározott célok elérésében. A modern társadalmakban a bizalom számos, a családi-baráti kapcsolathálón túli szereppartnerre is kiterjed, bízunk abban, hogy a munkájukat úgy végzik, hogy nem hátrányunk, hanem előnyünk származhat belőle (hivatalnokok, orvosok, tanárok). Ha jól meggondoljuk, az egészségügy mellett az oktatási rendszerrel kapcsolatban vállalják a társadalom tagjai a legnagyobb kockázatot, mikor megbíznak benne. Az oktatási rendszer - hierarchikus struktúrája, az egymásra következés elve és a csereközegét jellemző interdependencia miatt - kiemelkedően hoszszú távú bizalmat igényel a belépőktől (Green 1980). A belépéskori döntéskor hosszú távra vonatkozó elvárásai vannak az egyénnek, a családoknak, az általános iskolába lépéstől a munkába állásig. Olyan ez, mint egy szerződéses viszony kezdete. A tanulmányok során a megelőlegezett bizalom folyamatosan mérlegre kerül, s elvész vagy megerősíthető azoktól a tapasztalatoktól függően, hogy a tanuló vagy hallgató azt a szolgáltatást kapja-e és olyan (tanulmányi és anyagi) feltételekkel kapja-e, amivel belépéskor kalkulált (Green 1980).

Három szinten is szükség van a tanuló/hallgató bizalmára. Egyrészt a rendszer egészében, másrészt a konkrét intézményben, harmadrészt a feladatot ellátó személyekben szükséges megbízni az eredményes együttmüködés érdekében. A rendszerszintű bizalmat a minőségmenedzsment mellett az oktatáspolitika kiszámíthatósága, az oktatáshoz való alapjogok garantálása, a tanulási útvonalak stabilitása biztosítja. A rendszer változásai könnyen okozhatják a bizalmi alapú megegyezés összeroppanását. Az oktatási rendszer alapvető működési elve az egymásra következés, ezért a reformok átgondolt és felmenő rendszerü bevezetése nemcsak törvényben garantált követelmény, hanem a rendszerbe vetett bizalom fenntartásának feltétele.

Az oktatási intézmények fontos gyakorlóterepei a bizalomnak és a megbízhatóságnak, hiszen kikerülve a szoros családi kapcsolatháló feltétel nélküli bizalommal teli közegéből, itt szerezhetők az első cizelláltabb tapasztalatok, melyekben előrehaladva egyre bonyolultabb szervezeti szabályrendszert ismer meg az egyén. A szervezeti szabályrendszer stabilitása garantálja a biztonságot, az információhoz jutást, a hatalmi visszaélés elleni védelmet a tanulók, a hallgatók számára is. A tanulónak és a hallgatónak - az oktatás világában jelen levő kétségtelen függőségi helyzete miatt - biztosnak kell lennie abban, hogy az általuk választott intézmény átlátható procedúrákat alkalmaz, kiszámítható módon jár el az ügyeikben, valamint hogy a tanári, oktatói kar a fejlődése érdekében és kompetensen oktat, valamint korrekt módon értékel.

Mivel a személyközi bizalom az általánosított bizalom alapja, ahogy Simmel (2001) állította, az intézményi szereppartnerekbe vetett bizalom döntő az egyén meggyőződése szempontjából. A tanszemélyzet nem önmagát, hanem a tanulók számára nehezen érzékelhető teljes rendszert és intézményt is megjeleníti. Az oktatás világában a tanárok, oktatók iránti bizalom döntő abból a szempontból, hogy eredményes-e az oktatás, s hogy létrejön, illetve fennmarad-e az oktatási rendszer egészébe vetett bizalom (Green 1980; Tschannen-Moran-Hoy 2000; Tóth 2005; Kovács et al. 2018). 
Kétségtelen, hogy egy-egy szervezet működésével kapcsolatban az egyén megelőlegezi a bizalmat, amikor a szervezettel vagy annak képviselőjével kapcsolatba lép. A fogyasztás vagy a szolgáltatás világában a bizalom fennmaradásának feltétele az elvárások beteljesülése, a korábban megelőlegezett bizalom megerősítése. Az oktatási intézmények világában azonban, éppen az intézményhez kötöttség hosszadalmas ciklusai miatt, elemi tapasztalat a bizalmatlansággal teli, tehetetlen ráhagyatkozás is. Ez nem jár azonnal látványos szakítással, kilépéssel, a tehetetlenség még sodorja tovább a tanulókat, azonban a bizalomvesztés akár kilépést is vonhat maga után.

A pozitív szcenárió, ha fennmarad a bizalom és érvényesül multiplikátor szerepe is (Kováts 2019). A bizalommal teli együttmüködés várakozáson felüli teljesítményhez, eredményekhez segítheti a tanulót, ennek hiánya negatív hatással van a teljesítményre. Coleman társadalmi tőke elméletéből és Putnam bizalomértelmezéséből kiindulva Bryk és Schneider kimutatták, hogy a relációs bizalom növekedése a fejlődéshez szükséges biztonságérzetet eredményez, ami hozzájárul a tanulmányi és nevelési eredményességhez (Coleman 1988; Putnam 1995; Bryk-Schneider 2002). Ilyenkor a bizalom új, önálló szervezeti tulajdonságot hoz létre. De a bizalmatlanság is szervezeti jellemzővé válhat, ha az együttmüködők nem biztosak abban, hogy egymás érdekeinek tekintetbevétele kölcsönösen fontos, ha nem bíznak egymás kompetenciájában vagy lelkiismeretességében. Bryk és Schneider szerint a diákok, szülők és tanárok folyamatosan monitorozzák egymás magatartását, ehhez azonban folyamatosan fenntartott személyes kapcsolattartás szükséges. A személytelen szervezeti struktúrákban, amilyenné a felsőoktatás is vált, csak a hallgatók töredéke számol be a pedagógiai hatásgyakorláshoz szükséges kontaktusokról (Pusztai 2011).

A bizalom tudatos és öntudatlan építőkövei nehezen elkülöníthetők, a kutatók egy része szerint a bizalom forrása az objektív tapasztalás, az intézmények megelégedést keltő müködése (Tschannen-Moran-Hoy 2000; Uslaner 2002; Tóth 2005). Mások a szubjektív nézőpontot hangsúlyozzák, miszerint a bizalom olyan belső konstrukció, szemléletmód, melynek optikáján keresztül értelmezzük környezetünket (Simmel 2001; Putnam 1995; Pusztai 2011). Lin (2005) szerint a bizalom a kapcsolathálóban születő benyomás, s csak az a kérdés, hogy miképpen erősíti a személyes kapcsolatháló megbízható tagjainak nagy aránya vagy a bizalommal bíró társaknak a kontextusban tapasztalt sürüsége. Munkáinkban (Pusztai 2011, 2015) a bizalomra úgy tekintettünk, mint társas kapcsolatainkban megalkotott valóságkonstrukcióra, s az oktatás világában az együtt tanulók értelmező közösségként működnek (Pusztai 2011), ezért közösen alakítják ki állásfoglalásukat a kérdésben is.

A bizalom jelentősége éppen a hiányos müködés során mérhető fel. A kijátszás, a szószegés, a hátráltatás élményeit követő morális felháborodás és izoláció szoros összefüggésben áll egymással, egyrészt a személyközi, majd a generalizált bizalom megroppanását, általános anómiát von maga után (Kálmán 2013; Pusztai 2011). Ha a rendszerben megjelenik a kijátszás, ahogy Coleman rámutat, ez előbb-utóbb kölcsönössé válik. Így azonban az egész szervezet és környezete veszít vele (Coleman 1990; Orbán-Szántó 2005). Az oktatás világában különösen érvényes az a törvényszerüség, hogy az intézményen belüli normák kívülre is kiterjednek, a bizalom vagy a bizalmatlanság rádiusza a szélesebb társadalomra is hat a végzett hallgatók révén. Tény, hogy a hallgatók alacsony bizalomszintje, izoláltsága összefüggést mutat néhány oktatói mutatóval, az oktatók hallgatói színvonalról alkotott negatív véleményével, az oktató munka iránti alacsony 
elkötelezettséggel és az intézményvezetésbe vetett bizalom megrendülésével (Astin 1993; Jencks-Riesman 2002).

Pedig a felsőoktatási intézményeknek marketing szempontból is fontos a hallgatói bizalom, hiszen a hallgatók újabb képzésekbe való visszatérését, újrajelentkezését, illetve az új jelentkezők döntését is befolyásolja (Hetesi-Kürtös 2009). A felsőoktatási eredményességgel foglalkozó egyes modellek intézményi szintű eredményességi mutatóként tartják számon az általános bizalom megerősítését hallgatóikban, mert a későbbi társadalmi, munkahelyi magatartás számos tényezőjét előrejelzi (Camara-Kimmel 2005; Heuser 2007; Pascarella-Terenzini 2005).

\section{Kutatási kérdések}

Jelen tanulmányban arra fókuszálunk, hogy kik és miért bizalmatlanok. Feltételezhető lehetne természetesen, hogy az iskolázottsággal járó intellektuális előny miatt a magasabb végzettségüek hajlamosabbak a kételkedésre, a tartózkodásra, a bizalmatlanságra különösen a közintézményekkel szemben, s ezért alacsonyabb lehetne a bizalomszintjük. A korábbi kutatások azonban inkább azt valószínúsítik, hogy a magasabb iskolázottság erősebb bizalomérzéshez vezet, mert a képzettség kedvezőbb státussal jár együtt (Tóth 2005, 2010), s a kedvező körülmények és sikeres pályafutás erősebb bizalmat ébresztenek. A 2016-ban felvett Magyar Ifjúság vizsgálat $(N=8000)$ hallgatói adatait $(n=1029)$ elemezve elsőként arra a kérdésre kerestük a választ, hogy a milyen fó társadalmi és kulturális mutatók mentén rendeződik el a bizalom és a bizalmatlanság napjaink hallgatótársadalmában, s van-e olyan tényező, ami kompenzálja az alacsony státusúak bizalmi hátrányát. Magyarországi regionális hallgatói adatok (IESA 2015², $N=2017)(n=1226)$ alapján arra kérdeztünk rá, hogy egy hátrányos helyzetü régióban ugyanazok-e a társadalmi-kulturális törésvonalak a bizalommal teli és a bizalmatlan hallgatók között. A regionális hallgatói adatokon vizsgáltuk azt, hogy milyen kapcsolat áll fenn az általános bizalomszint és tanulmányok félbehagyása, az intézményből való kiábrándulás és a diplomaszerzésben való elbizonytalanodás között. Mivel feltételeztük, hogy a felsőoktatásban tanulók általános bizalomérzetét meghatározza az őket körülvevő intézményi környezet, megvizsgáltuk, hogy az egyetemen belüli és kívüli kontaktusok erőssége milyen kapcsolatban áll a bizalomérzettel. A regionális kutatásban álltak rendelkezésre az erre vonatkozó adatok. A lemorzsolódott hallgatók körében 2018-ban felvett adataink (DEPART, 2018, $N=605$ ) lehetőséget teremtettek arra, hogy megvizsgáljuk, hogy a bizalomvesztésnek milyen szerepet tulajdonítanak a tanulmányi kudarcban, valamint azt, hogy milyen különbségek vannak a tanulmányok befejezésében bízó (perzisztens), a bizonytalan és a lemorzsolódó hallgatók között az oktatói kapcsolattartást illetően.

A hallgatói bizalom vizsgálatának módszertana tekintetében nincs teljes konszenzus, mértékét többféleképpen próbálják megragadni az empirikus kutatások, a közintézményekbe vetett bizalom és a személyközi bizalom (MI 2016), valamint az általános bizalom (IESA 2015) felmérése sztenderdizált skálákkal van jelen az elemzett adatbázisokban. További mutatókkal vizsgáltuk az oktatási rendszer értékébe és elérhetőségébe vetett

A hallgatói eredményességre gyakorolt intézményi hatás című kutatást a Debreceni Egyetem támogatta (DERH/885/2013). 
bizalmat (MI 2016), illetve korábban általunk fejlesztett kérdéssorral a felsőoktatókhoz való viszonyt (IESA 2015).

\section{A hallgatói bizalom és az iskolázottság}

Az elemzés során magyarázatot kerestünk arra, hogy melyek a bizalom és a bizalmatlanság különbségeit generáló legmarkánsabb társadalmi tényezők a hallgatók körében. A legszélesebb körű adattal a Magyar Ifjúság Kutatás (MI 2016, $N=8015$ ) adatbázisa rendelkezik erről. A közintézményekbe vetett bizalom mellett az interperszonális bizalmat, valamint - közvetett módon - az oktatási rendszer megbízhatóságát vizsgáltuk a szülői iskolázottság tekintetében. A kutatás során 12 itemmel mérték a közintézményekbe vetett bizalom mértékét a fiatalok körében. A felsőoktatás hallgatói - mint ahogy a diplomások is - mindegyik intézményben jobban bíztak, mint a felsőoktatásba nem jutók, a kormányba és a politikusokba vetett bizalom tekintetében nem szignifikáns a különbség. A leginkább megbízhatóktól a legkevésbé bizalomra érdemesekig a következő sorrendbe állították az intézményeket: honvédség, rendőrség, polgármesterek, Alkotmánybíróság, bíróságok, köztársasági elnök, civil szervezetek, egyházak, országgyülés, kormány, bankok, biztosítók, politikusok. Bár az egyes szereplők helyezése önmagában is figyelemreméltó, ez esetben nem az egyes közintézmények szereplését, hanem az általános bizalomszint alakulását tekintettük vizsgálatunk tárgyának. Megállapítható, hogy a hallgatók összességében közepes bizalommal tekintenek a közintézményekre $(2,17-2,96)$. A közintézményekbe vetett bizalom összesített szintje alapján a válaszadókat három harmadra osztottuk, a legbizalmatlanabb alsó harmadra (átlaguk négyfokú skálán: 1,4), a legmagasabb bizalomszinttel rendelkező felső harmadra (átlag: 2,5) és az átlagos bizalomszinttel bíró középső harmadra (átlag: 3,2). ${ }^{3} \mathrm{Az}$ alacsony bizalomszinttel rendelkezők körében a hallgatók és a diplomások alulreprezentáltak, az alacsonyabb iskolázottságúak felülreprezentáltak. A fiatalok saját - a kikérdezés pillanatáig elért iskolai végzettsége és a közintézményekbe vetett bizalom szintje összefüggött, a felsőoktatási hallgatók bizalma erősebb volt, mint az alacsonyabb iskolai szinten tanulóké. A hallgatók körében mind az anya, mind az apa alapfokú iskolázottsága esetén magasnak bizonyult a bizalmatlan hallgatók aránya, a középfokú végzettségüek gyermekei körében már enyhe többségbe kerültek a legmagasabb bizalomszinttel rendelkezök a bizalmatlanokkal szemben. A magas iskolázottságú szülők gyermekei körében pedig kiemelkedő volt az erős bizalommal rendelkezők aránya (1. ábra). A közintézményekbe vetett bizalomhoz mint erőforráshoz való hozzáférés vonatkozásában jelentős törésvonalak húzódnak a magyar fiatalok körében az iskolázottság terén. A lakóhely településtípusa szerint nem azonosítható tendenciózus eltérés.

A kutatás során 6 itemmel mérték az interperszonális bizalom mértékét (általában az emberek, saját család, szomszédok, ismerősök, munkatársak, a frissen megismertek). ${ }^{4}$ $\mathrm{A} z$ interperszonális bizalom erősebb a közintézményekbe vetett hitnél $(2,64-3,64)$, s a háttérváltozók tükrében is kiegyenlítettebb. A felsőoktatási intézmények hallgatóinak interperszonális bizalomszintje alig valamivel erősebb a felsőoktatásba nem jutókénál.

A felső harmad teteje és a második harmad alja között a különbség 1,7.

4 Magyar Ifjúság 2016 kutatásban az összes válaszadó negyedét (2000főt) kérdezve vizsgálták meg az interperszonális bizalom állapotát. 


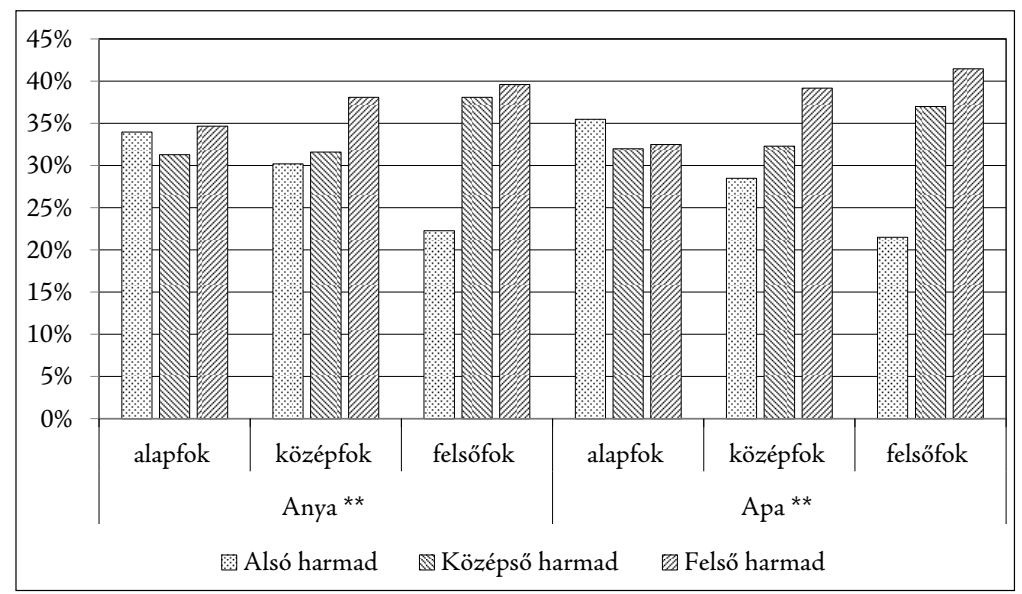

1. ábra: A hallgatók közintézményekbe vetett bizalomszintje a szülők iskolázottsága szerint (MI 2016). Khí-négyzet statisztika, ${ }^{* *} p \leq 0,03$

A leginkább megbízhatóktól a legkevésbé bizalomra érdemesekig a következő sorrendbe állították a szereplőket: családjuk, általában az emberek, ismerősök, szomszédok, munkatársak és ismeretlenek. Az interperszonális bizalom összesített szintje alapján a válaszadókat három harmadra oszthatjuk, a legbizalmatlanabb alsó harmadra (átlaguk négyfokú skálán: 2,7), a legmagasabb bizalomszinttel rendelkező felső harmadra (átlag: 3,2) és az átlagos bizalomszinttel bíró középső harmadra (átlag: 3,7) ${ }^{5} \mathrm{Az}$ interperszonális bizalomszint összességében nem függ össze a szülői iskolázottsággal, a felsőoktatásban tanulók felülreprezentáltak a magasabb bizalomszinttel rendelkezők körében. Az adatok azt mutatták, hogy miközben a közintézményekbe vetett bizalom státusfüggő jelenség, a primer tapasztalatokon nyugvó interperszonális bizalom szintje sokkal kevésbé függ az iskolázottságtól és a vallásosságtól.

Elemzésünk szempontjából kiemelten fontos az oktatásba vetett bizalom kérdése. Mivel a közintézmények között a kutatók nem sorolták fel a magyar oktatási rendszert vagy annak egyes intézményeit, nem tudunk nyilatkozni az oktatásügynek a közérdekű intézmények rangsorában betöltött helyezéséről. Az oktatásba vetett bizalomra indirekt módon kérdeznek rá: az egyes végzettségeknek tulajdonított értéken keresztül. ${ }^{6}$ Egyértelmü, hogy a közintézményekbe vetett bizalom szintje és az iskolarendszerben elnyerhető végzettségek értékébe vetett bizalom erősen összefügg egymással. Az általános iskola, az érettségi és a diploma értékéről való meggyőződés és a közintézményekbe vetett bizalom együttmozgása szignifikánsan pozitív irányú. Még fontosabb leszögeznünk, hogy az oktatási rendszerben elnyerhető javak értékének rangsorával kapcsolatban általános az egyetértés a társadalmi rétegek között: az összes megkérdezett fiatal körében (a szülői iskolai végzettség és a lakóhely településtípusa szerint külön is megvizsgálva) kimutatható, hogy a magasabb iskolai végzettségek értékében, beválthatóságában sokkal jobban bíznak a magyar fiatalok, mint az alacsonyabbakéban. Az adatfelvétel pillanatában még nem volt olyan kifejezett a nem diplomás foglalkozások iránti kereslet, mint

\footnotetext{
A felső harmad teteje és a második harmad alja között a különbség 0,33.

6 Ezt a kérdést kétezer fönek tették fel.
} 
az elemzés pillanatában, vélhetően azonban a végzettség értékének percepciója hosszabb távon is nagy stabilitást mutat, s nem kizárólag az aktuális munkaerőpiaci igények határozzák meg. A munkaértékek vizsgálata során több esetben tapasztaltuk a munkatípusok strukturális stabilitását (Pusztai 2009, 2015).

$\mathrm{A} z$ oktatási rendszerben elérhető egyre magasabb végzettség nagyobb értékében egyformán bíznak a különböző társadalmi hátterü hallgatók is. A 2016-os adatok szerint a leginkább értékelt végzettség egyértelműen a felsőfokú. Minden társadalmi csoport körében több mint kétszer akkora értéket tulajdonítanak a diplomának, mint az általános iskolai végbizonyítványnak. A szakiskolai végzettség és az érettségi értékét pedig lényegében azonosra taksálják, de ezek jelentősen elmaradnak a diploma hitelétől. Nemcsak az egyes iskolai végzettségek értéke, hanem a tanulási lehetőségekkel való elégedettség is nagyon erős összefüggést mutat a többi közintézménybe vetett bizalom szintjével és a szülő, valamint a fiatal iskolai végzettségével. Tanulságos, hogy miközben az alacsony státusúak gyermekei - mint láttuk - egyértelműen a felsőfokú végzettséget látják a legértékesebbnek, a tanulási lehetőségekkel szignifikánsan kevésbé elégedettek, mint a magasabb státusúak gyermekei. Az oktatási rendszerben való előrejutási lehetőségeik korlátozottságát egyértelmüen érzékelik.

\section{A bizalom és a vallásosság}

$\mathrm{A} z$ iskolázottság mellett a vallásosságnak a bizalomérzésre gyakorolt erőteljes hatását fontos kiemelnünk. A különböző státusmutatók mellett a vallásosság számos indikátora, például a vallásosság szerinti önbesorolás, a közösséghez tartozás, a vallásos neveltetés erős szignifikáns összefüggést mutat a közintézményekbe vetett bizalommal. Bár hazai viszonylatban a vallásosság és az iskolázottság közötti kapcsolat az utóbbi évtizedben átrendeződött, s a vallásosak körében egyre több a magasabb státusú, magasabb iskolázottságú fiatal, nem az iskolázottság szupresszor hatásáról beszélhetünk. Az összes megkérdezettnél, de még inkább a hallgatók körében szignifikáns hatása van a bizalomszint alakulására (Khí-négyzet statisztika, sig.: 0,003). Az egyháziasak fele, a maguk módján vallásosak kétötöde tekint a legnagyobb bizalommal a közintézményekre, míg a többi csoportban a bizalmatlanok vannak az átlagosnál többen (2. ábra). Azok

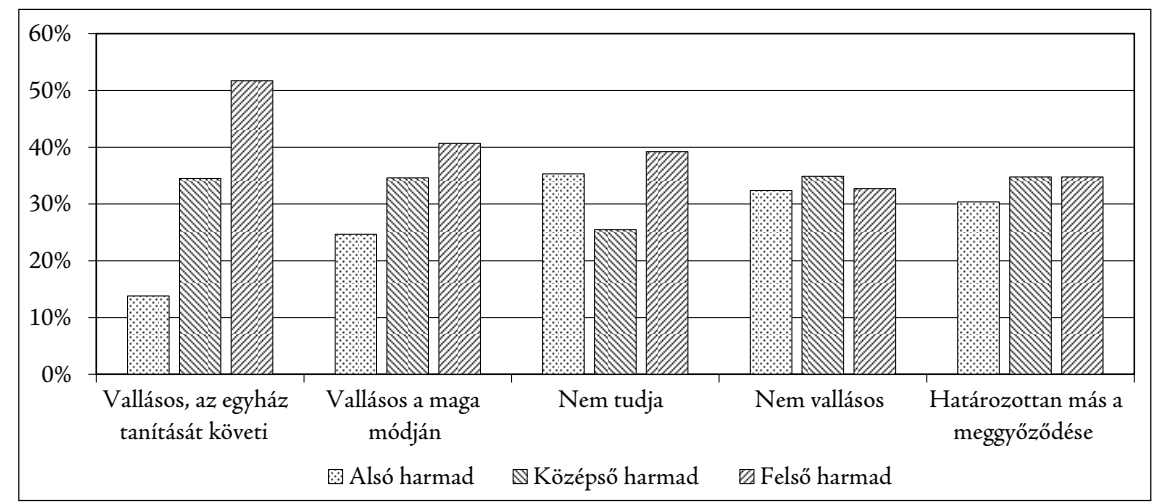

2. ábra: A közintézményekbe vetett bizalom mértéke a hallgatók vallásos önbesorolása szerint országos adatok alapján (MI 2016) 
közül, akiket vallásos nevelésben részesítettek vagy vallási közösségi tagként értelmezik magukat, szignifikánsan többen tartoznak a közintézményekben erősen bízók közé, mint azok, akik ettől eltérő neveltetést kaptak, vagy nem tartoznak közösségekhez (Khínégyzet statisztika, sig.: 0,000).

Ha a szülői iskolázottság és a vallásosság erős bizalomszint kialakulásának esélyére gyakorolt hatását logisztikus regressziós modellben összemérjük, az tapasztalható, hogy a vallásosságnak önálló pozitív hatása van (Exp.B: 1,596, sig.: 0,000). A többváltozós elemzés szerint a vallásosság valamivel jobban erősíti a bizalomszintet, mint az iskolázottság. Természetesen a vallásossá válás családi és kapcsolathálózati alapokon nyugszik, lehetetlen szándékosan növelni, míg az iskolázottság társadalmi szintje oktatáspolitikai eszközökkel befolyásolható. Az oktatási szinteken elérhető végzettségek értéke tekintetében a vallásossághoz való viszonytól függetlenül az tapasztalható, hogy a diploma felé haladva lépcsőzetesen magasabbra értékelik az egyes végzettségeket. Látványos eltérés még, hogy a vallásosak mindegyik végzettséget magasabbra értékelik, mint a többi válaszadó, egyedül a diploma értéke tekintetében nincs szignifikáns különbség. A tanulási lehetőségekkel való elégedettség is magasabb a vallásosak körében. A jelenséget nem először tapasztaljuk, a vallásosság optimistább ön-, társadalom- és jövőképhez segíti a fiatalokat (Pusztai 2009, 2011).

\section{A hallgatói bizalomhiány mint regionális jelenség}

Az eddigiek alapján egyértelmü, hogy egyéni szinten az alacsony státusnak döntő hatása van a közintézményekbe vetett bizalomra, és arra is, hogy mennyiben bíznak abban, hogy céljaik elérésében őket az oktatási rendszer támogatja. Kérdés, hogy milyen állapotban van a hallgatói bizalom a korábbi kutatások alapján egyértelmüen a leghátrányosabb helyzetü hallgatókat befogadó régió egyetemein (Szemerszki 2010; Pusztai 2010; Hegedüs 2016; Polónyi 2018). „A hallgatói eredményességre gyakorolt intézményi hatás” (IESA 2015) című kutatásban a bizalom mérésére az Európai Értékrend Vizsgálatban is alkalmazott, háromitemes általánosított bizalomra vonatkozó skálát használtuk, mely három dimenzióban hasonlítja össze a hallgatókat (Tóth, 2005). Arra válaszoltak a hallgatók, hogy mennyire értenek egyet azzal, hogy az emberekben meg lehet bízni, hogy az emberek többsége megpróbál tisztességes lenni, illetve az emberek megpróbálnak segíteni a másikon.

Jelen adatok összehasonlítása során is tapasztalható a régió hallgatóinak eltérő háttere. Míg az országos hallgatói almintában a szülők kétötöde felsőfokú végzettségü, addig a kelet-magyarországi hallgatók körében az apák egynegyede, az anyák egyharmada diplomás, miközben az alapfokú végzettségüek aránya Kelet-Magyarországon jóval magasabb mindkét szülő esetén, de az apák esetén különösen (3. ábra). Ez nemcsak azt jelenti, hogy a családok más tapasztalatokkal és lehetőségekkel rendelkeznek, hanem azt is, hogy az intézményekben együtt mozgó hallgatók túlnyomórészt családjukban elsőként küzdenek a felsőoktatás bonyolult, sokszor kiismerhetetlen világával, s egymást sem tudják tanácsokkal segíteni (vö. Pusztai 2011).

A kelet-magyarországi felsőoktatási hallgatók körében is eltérés tapasztalható a bizalomszint tekintetében a szülői végzettség szerinti csoportokban, de a szülők iskolázottsága nem befolyásolja olyan erősen a bizalomszintet, mint az országos adatok mutatták (khí-négyzet statisztika, $p \leq 0,05$ ) (4. ábra). Ennek az az oka, hogy ebben 


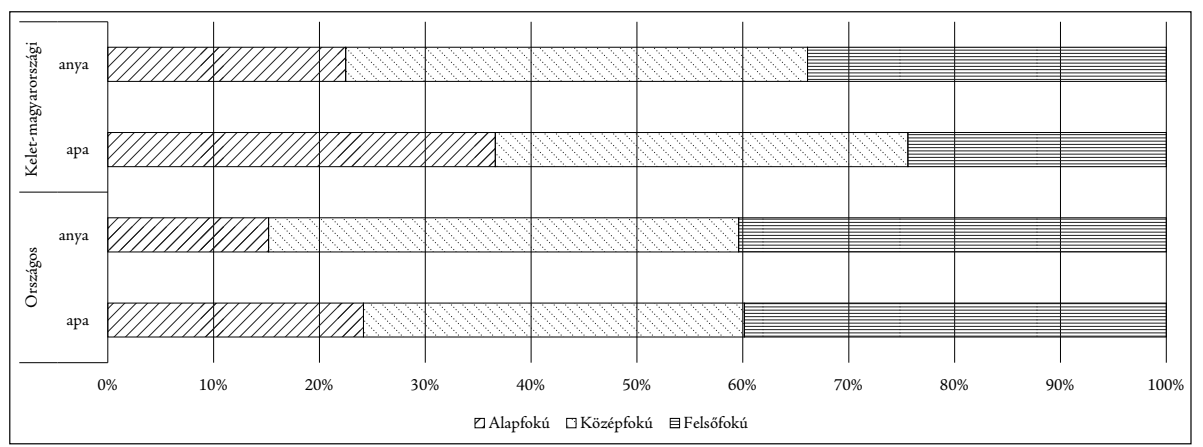

3. ábra: A hallgatók országos és regionális mintájának összetétele a szülők legmagasabb iskolai végzettsége szerint (MI 2016, IESA 2015)

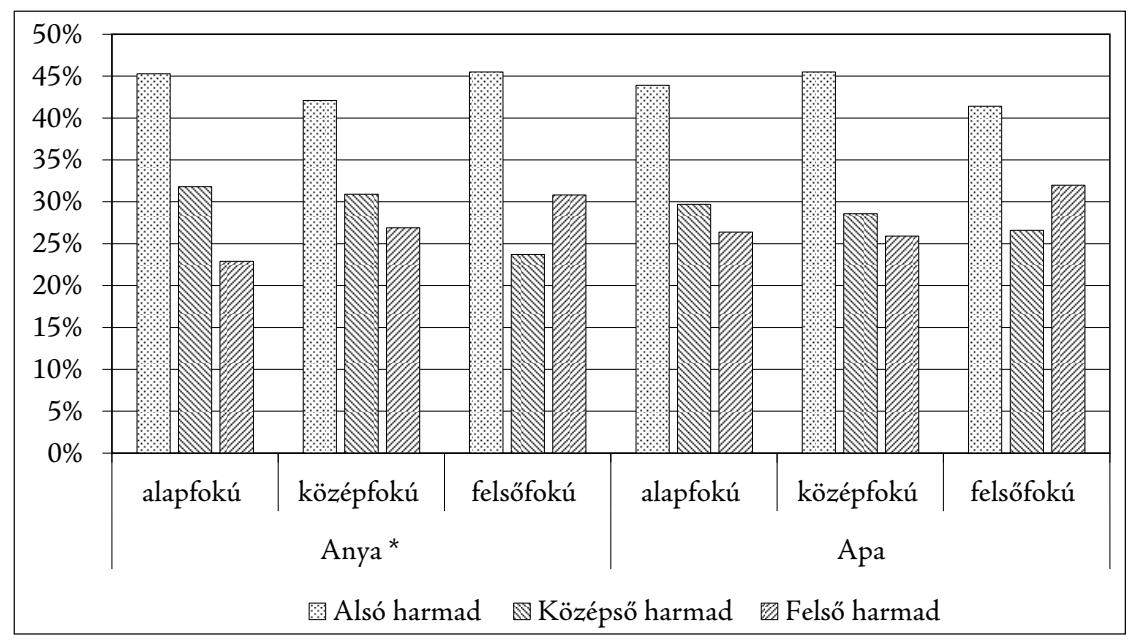

4. ábra: Az általános bizalom mértéke a szülők iskolázottsága szerint kelet-magyarországi hallgatók körében (IESA 2015)

a régióban alapvetően minden csoportban magas a bizalmatlanok aránya. A hallgatók kétötöde a szülei iskolázottságától függetlenül bizalmatlan, de itt is elmondható, hogy a legerősebb bizalomszinttel rendelkezők a magas iskolázottságú szülők gyermekei között fordulnak elö.

Mivel az országos adatok szerint a vallásosság önálló hatótényező, mely képes kompenzálni az alacsony iskolázottságúak bizalmatlanságát, megvizsgáltuk azt, hogy a vizsgált régióban hogyan módosítja a vizsgált tényezők viszonyát. A kelet-magyarországi mintában a vallásos önbesorolás szerinti csoportok aránya egy kevéssé eltér az országostól (mintegy 7\%-kal többen mondják magukat egyháziasnak, és ugyanennyivel kevesebben nem vallásosnak). Az egyházuk tanítását követők körében a diplomás apák gyermekei vannak felülreprezentálva, a maguk módján vallásosak körében pedig az alapfokú végzettségű apák gyermekei. A vallásosság és a bizalomszint összefüggése nem olyan markáns, mint országosan láttuk (5.ábra). Mindegyik önbesorolási csoportban a 


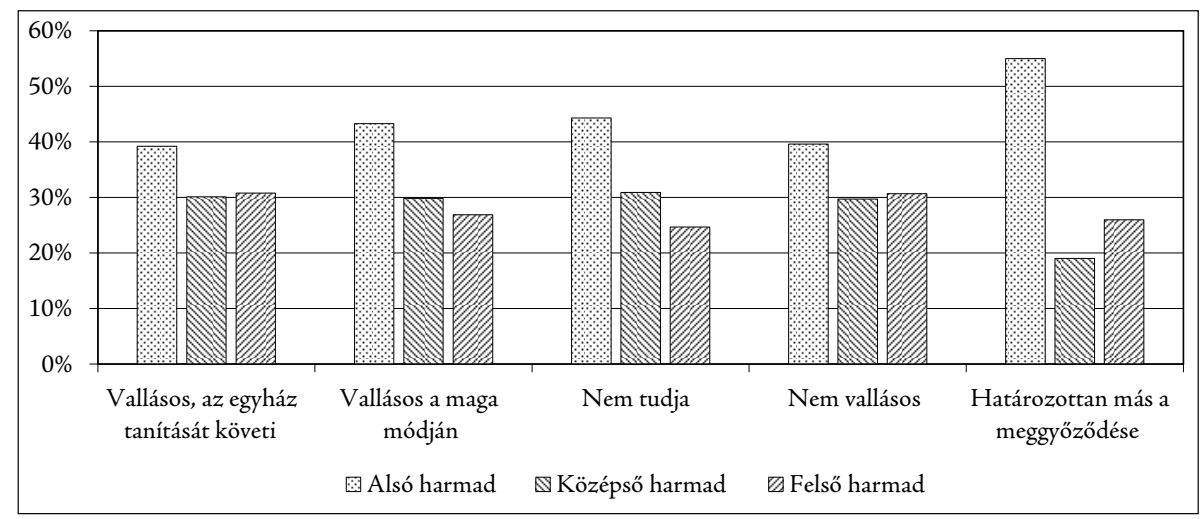

5. ábra: A bizalom mértéke a hallgatók vallásos önbesorolás szerinti csoportjaiban (MI 2016, IESA 2015)

bizalmatlanok vannak túlnyomó többségben, a vallásosság és a bizalom összefüggése a régióban nem szignifikáns. Sem a magasabb iskolázottságú szülői háttér, sem a vallásosság önmagában vagy együtt nem képes az általánosított bizalmat erősíteni. Ez a régió társadalmi-gazdasági hátrányával együttjáró pesszimistább világlátás számlájára írható.

\section{Hallgatói bizalom és felsőoktatási pályafutás}

Mint láttuk, a kelet-magyarországi régióban a hallgatók bizalmatlansága masszívan jelen van, s a szokásos kompenzáló tényezők (iskolázottság és vallásosság) sem segítenek ezen a tényen. A nehezen megszerzett bizalom eredményességre gyakorolt hatása ennek ellenére igazolható. Három, a kudarcos felsőoktatási pályafutás elkerülését fémjelző indikátornak a bizalommal való összefüggését vizsgáltuk, melyek a tanulmányok befejezéséhez és az intézményhez való ragaszkodást reprezentálták. Mivel a hallgatók bő tizede már túlesett egyszer felsőoktatási lemorzsolódáson, vizsgáltuk a képzést félbehagyók bizalommutatóit. A hallgatók kétharmada újraválasztaná a jelenlegi intézményét, s valamivel több mint kétharmaduk biztos abban, hogy be tudja fejezni a tanulmányait és diplomát szerez. A félbehagyók (khí-négyzet statisztika, sig.: 0,001), az intézményüket újra már nem választók (sig.: 0,000) és a diplomaszerzés sikerében bizonytalanok (sig.: 0,000) körében magasan felülreprezentált az erősen bizalmatlanok aránya, míg a tanulmányaikat korábban meg nem szakítók, az intézményüket - esetleges továbbtanulás esetén - újraválasztani szándékozók, valamint a diplomaszerzésben biztosak körében az erős bizalommal rendelkezők vannak túlsúlyban (6. ábra).

Értelmezés kérdése, hogy a fenti összefüggésekben az általános bizalomérzet ok vagy okozat, azonban kétségtelen, hogy a vizsgált mutatók és a bizalomszint között erős a korreláció. Ilyen körülmények között kulcskérdés az, hogy milyen felsőoktatási intézményen belüli és kívüli aktorok képesek támogatni a hallgatói bizalom növelését. A hallgatót körülvevő kapcsolathálóban elérhető kontaktusok, tanulmányi és személyes támogatás vizsgálatára fejlesztettük ki a kapcsolati beágyazódást vizsgáló mérőeszközünket (Pusztai 2005, 2011). Az elemzés azon a feltevésen nyuszik, hogy az intézményen kívüli és belüli kontaktusok sokoldalúsága, erőssége a hallgató eredményességét támogató erőforrás. Jelen elemzésben azt vizsgáltuk, hogy a bizalomszint és az átlagos- 


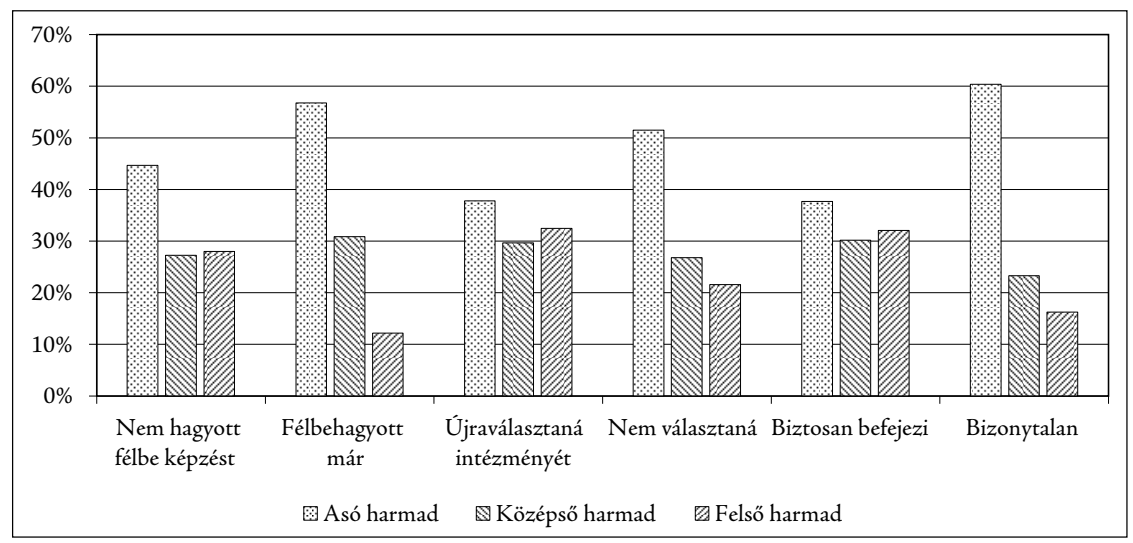

6. ábra: Bizalomszint a hallgatói előrehaladás szerinti csoportokban (IESA 2015)

nál erősebb kapcsolatokkal rendelkezők aránya hogyan függ össze. Az oktató-hallgató kontaktusok esetén a mutatók a tananyagról, tudományos kérdésekröl, tananyagon kivüli témákról, szépirodalomról, müvészetröl, köz-és magánéleti kérdésekröl, jövőtervekröl való beszélgetés, e-mail kapcsolat, személyes odafigyelés voltak. A kortárs kapcsolatok esetén a tanulmányi, tudományos és magánéleti témákkal, jövötervekkel, kultúrával, közélettel kapcsolatos beszélgetések, közös tanulás és szabadidös tevékenységek, kölcsönös beteglátogatás, jegyzetmegosztás és a szülökhöz füződő kapcsolatok területén a tanulmányokról, szabadidős tevékenységekröl, szakmai jövőtervekröl, kultúráról, közéletröl és magánéletről szóló beszélgetések, közös szabadidö és munkavégzés, anyagi támogatás, barátokkal, tanárokkal való találkozás. A kapcsolatok sokoldalúsága (multiplexitás) növeli annak támogató erejét. Az oktatók felé irányuló kapcsolatok kivételével a többiek erősebbek, sokoldalúbbak. A szűkebb spektrumú, gyengébb kapcsolattartás gyengébb bizalomszinttel jár együtt (7. ábra). Az ábráról leolvasható, hogy a hallgatói bizalom mértékét nemcsak az növeli, ha a szüleivel és kortársaival sokoldalú, multiplex kapcsolatai vannak a hallgatónak, hanem az oktatói figyelem is önálló, szignifikáns eltérést idéz elő. A személytelenné vált

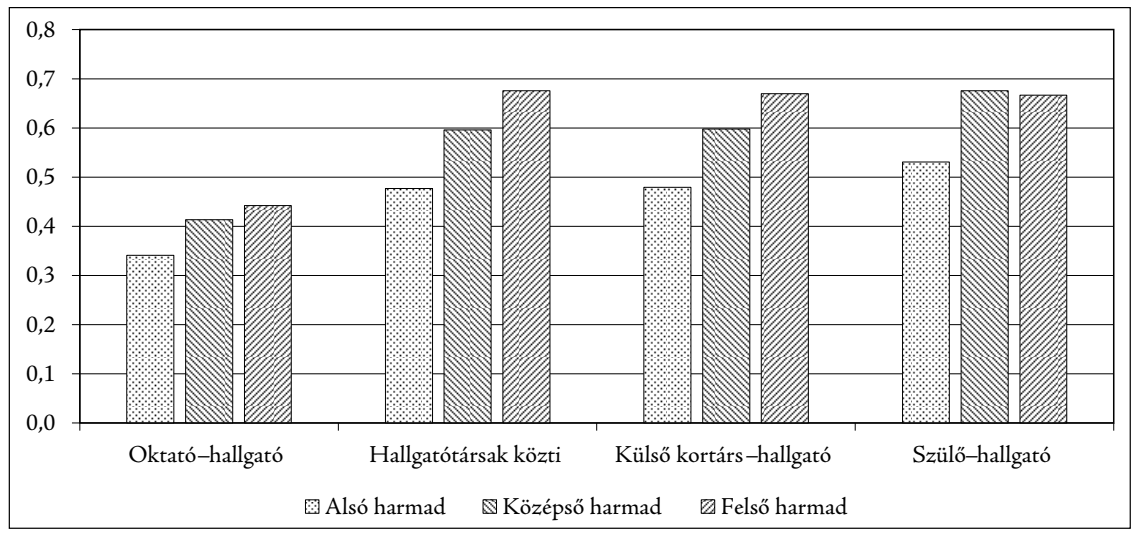

7. ábra: A hallgatói kontaktusok erőssége a hallgatók általános bizalomszintje szerinti csoportokban (IESA 2015) 
tömeges felsőoktatásban ennek a tudatosítására és erősítésére nincs törekvés, a tudományos diákköri munkában, a doktori képzésben és a szakkollégiumi hálózatban sem általános ez a fajta tutori tevékenység.

\section{Bizalmatlanság és lemorzsolódás}

A felsőoktatásból végzettség nélkül távozó ún. lemorzsolódottak $(N=605)$ körében a tanulmányok félbehagyásának okai között jelentős tényezőcsoportnak bizonyult a bizalomhiány. 2018 tavaszán lemorzsolódott hallgatókat kérdeztünk meg a felsőoktatási pályafutásuk sikertelenségének okairól. Az adatfelvételt kvalitatív interjús vizsgálat előzte meg, így a vizsgált dimenziók érvényessége erős. A lemorzsolódottakat hólabda módszerrel értük el, s összesen 40 felsőoktatási intézmény 605 lemorzsolódott hallgatójának válaszait tartalmazza a DEPART 2018 adatbázis. A minta természetszerüleg nem reprezentatív, viszont a felsőoktatás felől nehezen elérhető, rejtőzködő csoportot sikerült elérni. A lemorzsolódásról szóló hallgatói interpretációkat sokoldalú elemzésnek vetettük alá, jelenleg csupán a bizalomhiány megjelenésének eseteire koncentrálunk. A lemorzsolódottak ugyanis gyakran neveztek meg a lemorzsolódás okaként olyan tényezőket, melyek bizalmatlanságról, bizalomvesztésről, kijátszottság érzéséről tanúskodtak. A harmadik leggyakoribb magyarázat volt az oktatók inkorrektsége, a hetedik az önbizalomhiány, a kilencedik az intézményi adminisztráció hátráltató magatartása. A hallgatók bő egyharmada $(36,7 \%)$ szerint az oktatói magatartás, majd egyharmada szerint (32\%) az adminisztráció hiányosságai, s bő egyharmad szerint $(35,7 \%)$ a kudarcok miatti önbizalomvesztés okozta a lemorzsolódásukat. A hallgatótársak segítőkészségének hiánya is megjelenik problémaként, ez valamivel több mint a hallgatók egytizedének bizalomvesztését okozta (8.ábra). Összességében azonban a hallgatók több mint kétharmada azzal magyarázta kudarcát, hogy legalább két szereppartnerben elveszítette a bizalmát.

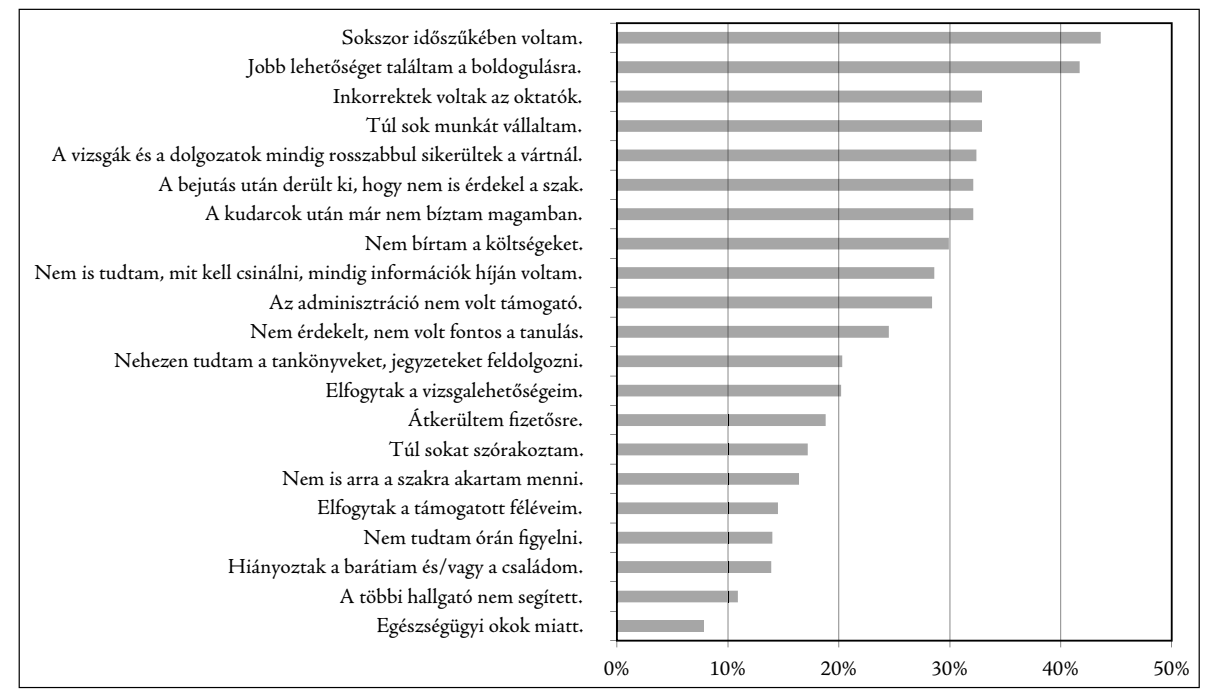

8 ábra: A különböző lemorzsolódási okokat megjelelő hallgatók aránya (DEPART 2018) 
Ami a háttértényezőket illeti, a bizalomvesztéses lemorzsolódás a férfihallgatókat gyakrabban jellemezte, a szülők iskolázottsága szerinti csoportok között azonban nem volt szignifikáns különbség. A lemorzsolódási döntés meghozatalában az oktatóktól csak kevesebb mint a hallgatók egytizede kért tanácsot, s a karriertanácsadással foglalkozó egyetemi munkatársaktól mindössze nyolc százalék. A lemorzsolódók több mint egyharmada a szülőkkel konzultálva döntött tanulmányai félbeszakítása ügyében, s jellemző módon a bizalomvesztők felülreprezentáltan csak velük értekeztek e fontos lépést megelőzően. Ez arra vall, hogy a felsőoktatási intézmények sem megelőzni, sem kezelni nem tudták a hallgatói bizalomvesztést. A hallgatók a szülőkre vannak utalva, akik viszont kevéssé tudnak segíteni. Még a diplomás szülőknek sincs elegendő tapasztalatuk, hogy eligazodjanak a felsőoktatás egyre bonyolultabbá váló világában, hiszen az egy másfél-két évtizeddel ezelőtt felsőoktatási tanulmányokat folytatóknak is ismeretlen a kreditrendszer, a tárgyfelvételi feltételek és a súlyozott átlagszámítás feltételei között folyó tömegképzés, s a személytelen felsőoktatási struktúrák világát el sem tudják képzelni.

Mivel az intézményi magatartás a hallgatók számára elsősorban az oktatói magatartásban reprezentálódik, összehasonlítottuk a lemorzsolódottak, a tanulmányaik befejezésében bizonytalanok és a sikeres végzésükben biztos hallgatók percepcióit az oktató-hallgató kontaktusokról. Eredményeink különböző adatbázisokból származnak, azonban a hallgatói csoportokat azonos kérdésekkel kerestük meg. Az összehasonlítás nyomán kirajzolódik azoknak a tevékenységeknek a sora, amelyeket jelentősen eltérő arányban tapasztalnak a lemorzsolódottak és azok a hallgatók, akik biztosak abban, hogy befejezik a tanulmányaikat (perzisztensek). A nyolc mutató közül egyedül a magánéleti beszélgetésekben volt részük gyakrabban a lemorzsolódottaknak a perzisztensekhez képest. A lemorzsolódottak legnagyobb lemaradása a tananyagról, tudományos kérdésekről és

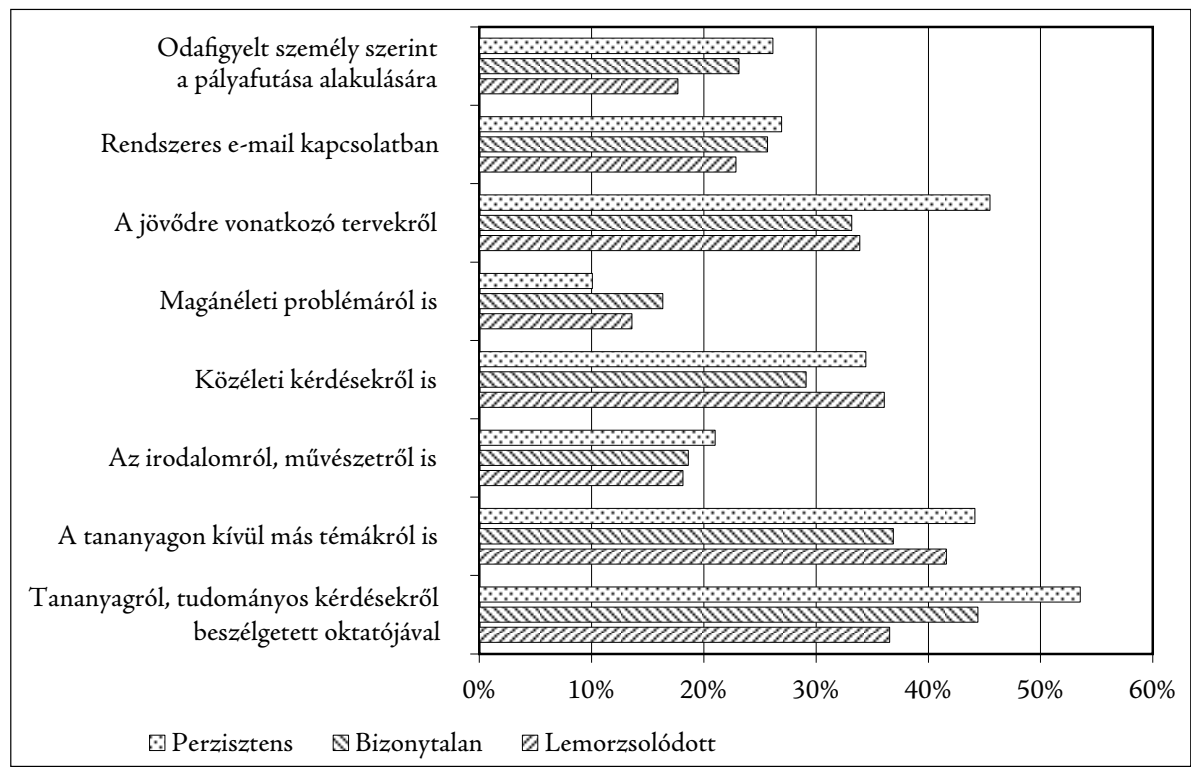

9. ábra: Oktatókkal való kapcsolattartás a perzisztensek, bizonytalanok és a lemorzsolódottak körében (Forrás: IESA 2015, DEPART 2018) 
a jövőtervekről való beszélgetés, a tanulmányi pályafutásra való személyes odafigyelés percepciója és az elektronikus kapcsolattartás lehetősége tekintetében volt (9. ábra). A tananyagon kívüli témák, a közéleti kérdések megbeszélésének elmaradása is hiányérzetet okoz a bizonytalan, egyelőre még a felsőoktatásban haladó hallgatóknak, akiknek mutatói még kedvezőtlenebbek ezen a téren a lemorzsolódottakénál is.

$\mathrm{A} z$ adatok szerint a perzisztenciát elősegítő oktatói magatartás hatékonyan elősegíthetné a hallgatói kontaktusok bizalomerősítő hatásának fenntartását. A hazai oktatáskutatók még adósok a felsőoktatók vizsgálatával, s Magyarország a Teichler vezette összehasonlító kutatásokban sem vett részt, így nincs adatunk arra vonatkozólag, hogy mennyire érzik a fent említetteket feladatuknak az oktatók, illetve milyen szervezeti tényezők hátráltatják ebben őket. Az azonban nem kétséges, hogy az oktatói szerepkör maga is válságba került a szétdifferenciálódó intézményi rendszerekben (Pusztai 2011; Teichler-Cummings 2015). A jövő generáció szakmai fejlődéséhez, a képzési erőforrások értelmes felhasználásához azonban bizalmi helyzet megteremtése és fenntartása szükséges, aminek élettere a személytelenné és átláthatatlanná vált szervezetekben lehetetlenné vált.

\section{Összegzés}

Tanulmányunkban azt vizsgáltuk, hogy a mai magyar felsőoktatási hallgatók milyen mértékben rendelkeznek a közintézmények iránti, a konkrét személyközi vagy az ún. általánosított bizalommal. Habár a bizalom mérésének módszertana a vizsgált adatbázisokban nem egységes, a bizalom különböző mutatói a tanulmányi pályafutás pozitív vagy negatív fejleményeivel rendre összefüggést mutatnak. Az elemzés során azt tapasztaltuk, hogy miközben az országos hallgatói adatok szerint a közintézményekbe vetett bizalom szintje a legalapvetőbb társadalmi egyenlőtlenségi dimenzió, az iskolázottság hatására eltéréseket mutat, az egyenlőtlenségeket korrigálják a vallásosság szerinti különbségek. A kelet-magyarországi intézmények hallgatói között azonban a két egyenlőtlenségi dimenzió megfigyelésekor sem voltak erős eltérések, mivel a bizalmatlanok aránya minden csoportban meglehetősen magas. Tanulmányunkban amellett érveltünk, hogy a hallgatói bizalom nem egyszerűen egy a sok, nagy változatosságot mutató társadalmi jelenség közül, hiszen a felsőoktatási pályafutás alakulásával jelentős összefüggést mutat, amikor a tanulmányok félbehagyását, az intézmény újraválasztását és a lemorzsolódás rizikóját jelző bizonytalanság alakulását is magyarázza. Mivel a bizalom alapvető feltétele a szereppartnerek szándékainak átláthatósága, a felsőoktatás személytelensége, az intézmény magatartását reprezentáló szereplőkkel kapcsolatban szerzett negatív tapasztalatok súlyos bizalomhiányt konzerválnak a rendszerben. Az oktatókkal való kontaktusok szegényessége nemcsak a bizalomhiánnyal áll összefüggésben, hanem az is egyértelmü, hogy a lemorzsolódottak és a bizonytalanok hiányt szenvednek az oktatói odafigyelésben.

Tanulmányunkban új kutatási eredményeket mutattunk be a felsőoktatási pályafutás és a bizalom kapcsolatát illetően. A bizalom társadalmi státussal való összefüggésére mások is rámutattak, ugyanakkor az iskolázottság és a vallásosság bizalomra gyakorolt együttes hatásával és regionális változataival nem foglalkoztak a hazai oktatáskutatók. A hallgatói eredményesség és a felsőoktatási intézménybe való beágyazódás, különösképpen az oktatókkal való sokoldalú együttmüködés összefüggésére magunk mutattunk rá 2011-es monográfiánkban és számos tanulmányban, azonban a lemorzsolódott és a 
felsőoktatásban tanuló - lemorzsolódási rizikóval küzdő vagy perzisztens - hallgatók oktatói kapcsolatai eddig nem kerültek összehasonlításra, s emiatt korábban nem volt megfogalmazható a személytelen felsőoktatási viszonyrendszernek a nagyarányú lemorzsolódásban játszott közvetlen felelőssége.

A kutatásunk eredményei alapján mértéktartó és óvatosan általánosítható következtetések vonhatók le, mert nem minden adatbázisban szerepeltek ugyanazok a mérőeszközök. Mindazonáltal a tanulmány arra hívja fel a figyelmet, hogy a hallgatói bizalmatlanság, legyen az általános, közintézményeket, köztük az oktatási rendszert érintő vagy az intézményi szereppartnerekre (oktatók, adminisztrátorok) vonatkozó, összességében egyazon társadalmi tény többféle arca, ami a következő diplomás generációk társadalmi otthontalanságának előrejelzője lehet.

\section{IRODALOM}

Astin, A. W. (1993) What Matters in College: Four Critical Years Revisited. San Francisco (CA) Jossey-Bass.

Bryk, A. S. \& Schneider, B. (2002) Trust in Schools: A Core Resource for Improvement. New York, Russel Sage Foundation.

Camara, W. J. \& Kimmel, E. W. (eds, 2005) Choosing Students. Higher Education Admissions Tools for the 21st Century. London, Lawrence Erlbaum Associates.

Coleman, J. S. (1988) Social Capital in the Creation of the Human Capital. American Journal of Sociology, Vol. 94. No. 1. pp. 95-120.

Coleman, S. J. (1990) Foundations of Social Theory. Cambridge, Harvard University Press.

Green, T. F. (1980) Predicting the Behaviour of Educational Systems. New York, Syracuse University Press.

Hegedưs R. (2016) Számok-arányok-mintázatok a felsőoktatásba felvett hátrányos helyzetüek esetében. Modern Geográfia, Vol. 16. No. 3. pp. 1-13.

Hetesi E. \& Kürtösi Zs. (2009) A felsőoktatás képzési teljesítményének mérési problémái. In: Hetesi E., Majó Z. \& Lukovics M. (eds) A szolgáltatások világa. Szeged, JATE Press. pp. 168-185.

Heuser, B. L. (2007) Academic Social Cohesion within Higher Education. Prospects, Vol. 37. No. 3. pp. 293-303.

Jencks, C. \& Riesman, D. (2002) The Academic Revolution. New York, Doubleday.

Kálmán O. (2013) Tanulástámogatás a felsőoktatásban. Felsőoktatási Mühely, Vol. 7. No. 2. pp. 15-22.

Kovács K., Bába É., Juhász Cs., Máthé E., Kocsis I., Fenyves V. \& Nagy B. (2018) Két tanév tantárgyainak vizsgálata sikertelen teljesítés szempontjából a DE Gazdaságtudományi Kar hallgatói körében. In: Pusztai G. \& Szigeti F. (eds) Lemorzsolódás és perzisztencia a felsőoktatásban. Debrecen, Debreceni Egyetem Kiadó. pp. 250262.

Kováts G. (2018) Sokszínű bizalom. Educatio, Vol. 27. No. 4. pp. 531-547. DOI: $10.1556 / 2063.27 .2018 .001$.

Lin, N. (2005) Social Capital. In: J. Beckert \& M. Zagiroski (eds) Encyclopedia of Economic Sociology. London, Routledge. pp. 604-612.

Orbán A. \& Szántó Z. (2005) Társadalmi tőke. Erdélyi Társadalom, Vol. 3. No. 2. pp. 55-70. 
Pascarella, E. T. \& Terenzini, P. T. (2005) How College Affects Students. San Francisco, Jossey-Bass

Polóny I. (2018) A hátrányos helyzetű régiók felsőoktatási rekrutációjának néhány sajátossága. In: Pusztai G. \& Szigeti F. (eds) Lemorzsolódás és perzisztencia a felsöoktatásban. Debrecen, Debreceni Egyetem Kiadó, pp. 207-224.

Pusztai G. (2009) A társadalmi töke és az iskola. Kapcsolati erőforrások hatása az iskolai pályafutásra. Budapest, Új Mandátum Könyvkiadó.

Pusztai G. (2010) Egy határmenti régió hallgató-társadalmának térszerkezete. In: JuHász E. (ed.) Harmadfokú képzés, felnöttképzés és regionalizmus. Régió és oktatás V. Debrecen, Center for Higher Education Research and Development Hungary. pp. 43-56.

Pusztai G. (2011) A láthatatlan kéztöl a baráti kezekig. Hallgatói értelmezö közösségek a felsöoktatásban. Busapest, Új Mandátum Kiadó.

Pusztai G. (2015) Pathways to Success in Higher Education. Rethinking the Social. Capital Theory in the Light of Institutional Diversity. Frankfurt am Main, Peter Lang.

Putnam, R. D. (1995) Bowling Alone: America's Declining Social Capital. Journal of Democracy, Vol. 6. No. 1. pp. 65-78.

Simmel, G. (2001) A társasság. In: G. Simmel: Válogatott társadalomelméleti tanulmányok. Budapest, Novissima Kiadó. pp. 168-180.

Szemerszki M. (2010) Regionális eltérések a harmadfokú továbbtanulásban. In: Kozma T. \& Ceglédi T. (eds) Régió és oktatás: A Partium esete. Debrecen, Debreceni Egyetem Felsőoktatási Kutató és Fejlesztő Központ. pp. 172-188.

Teichler, U. \& Cummings, W. (2015) Forming, Recruiting and Managing the Academic Profession. New York, Springer.

Tóтн I. Gy. (2005) Kockázat, bizalom és részvétel a magyar gazdaságban és társadalomban. Budapest, TÁRKI.

Tóтн I. Gy. (2010) A társadalmi kohézió elemei: bizalom, normakövetés, igazságosság és felelősségérzet. Társadalmi Riport, Vol. 11. No. 1. pp. 254-287.

Tschannen-Moran, M. \& Hoy, K. W. (2000) A Multidisciplinary Analysis of the Nature, Meaning, and Measurement of Trust. Review of Educational Research, Vol. 70. No. 4. pp. 547-593.

Uslaner, E. M. (2008) Trust as a Moral Value. In: D. Castiglione, J. W. van Deth $\&$ G. Wolleb (eds) The Handbook of Social Capital. Oxford, Oxford University Press. pp. 101-121.

A cikk a Creative Commons Attribution 4.0 International License (https://creativecommons.org/licenses/ by/4.0/) feltételei szerint publikált Open Access közlemény, melynek szellemében a cikk bármilyen médiumban szabadon felhasználható, megosztható és újraközölhető, feltéve, hogy az eredeti szerző és a közlés helye, illetve a CC License linkje és az esetlegesen végrehajtott módosítások feltüntetésre kerülnek. (SID_1) 